\title{
Learning Style Preferences of Management Student Viz a Viz other disciplines and its implications on Education
}

\author{
Suruchi Pandey ${ }^{1}$, Srividhya Sainath ${ }^{2}$ \\ \{suruchi.p@sims.edu ${ }^{1}$, srividhya.sainath2018@sims.edu $\left.{ }^{2}\right\}$ \\ Symbiosis Institute of Management Studies, Symbiosis International (Deemed University), Pune ${ }^{1,2}$
}

\begin{abstract}
The current study was conducted to identify learning style preference of Fulltime students and to simultaneously analyze the relationship between learning style of a student with their gender, ethnic background, age, work experience and educational qualification. This study was conducted by circulating an appropriate two-part questionnaire to full-time students pursuing courses in the field of Science, arts and management. The first part comprised of the Learning style survey with 44 item questions that could measure the four learning style dimensions while the second part comprised of questions pertaining to Gender, Age, Nationality, Degree pursuing, and Work experience. Findings from the paper showed that Age, Gender, Work experience and Nationality influenced significantly the learning style preference of students. Also, higher education learners with more than 4 years of work experience displayed balance learning style while students with fewer years of work experience showed strong or moderate preference for at least one learning style. Industries and Educational institutions today have realized the importance of effective learning. Companies are investing on creating a robust learning atmosphere to improve their talent management system. Educational institutions have realized that a "One Size fits all" approach cannot be considered while educating the newer generation, and therefore finding ways to develop an effective pedagogy. Analyzing learning style preference can therefore be helpful in improving this process
\end{abstract}

Keywords: Learning Style, Management Students, Higher Education

\section{Introduction}

Organizations are starting to understand the importance of Learning. A well-established Learning and development program help employees perform better and ultimately contribute directly to the bottom line of the organization. Therefore, in the recent past companies are investing on creating a robust learning within their organization. Also, Economic development and advancement of a nation in expanding its competitiveness and population's quality of life, is without a doubt subject to the interest in human capital (Mansur, Kogid \& Madals,2010). In a developing nation such as India, it is of outmost importance to provide quality training to its human capital. Creating and engaging human capital with the goal that they are proficient to move to the new innovation world flawlessly, ought to be the best need of governments particularly in nations like India (Kapoor). Therefore, relevant and effective training needs to be identified and provided to align human capital skills to meet the futuristic needs of the Nation (Seven, Bagcivan, Kilic \& Acikel, 2012). 
Learning is a procedure that incorporates consistent and perpetual changes which happen in the mentalities of individuals by redundancy or experience. In ordinary conditions, everybody who is rationally well has the learning capacity, yet this procedure is quick and simple for a few while it is moderate and troublesome for some others (Topuz \& Karamustafaoglu, 2013). The inception of learning style is attributed to Dunn \& Dunn researchers in the early 1960s. Dunn \& Griggs (1988) investigated historical and then learning styles, they affirmed the use of definition which is still in relevant even now "Learning style is comprised of biological and developmental characteristics that make the identical instructional environments, methods, and resources effective for some learners and ineffective for others" (Dunn \& Dunn, 1972, 1992, 1993, 1979, 2000). Dunn and Dunn (1993) established the fact that, learning style is the manner in which learner begin to concentrate, process, internalize and remember information which is new or difficult. The learning style is a continuous and consistent process (Claxton \& Ralston, 1978). It demonstrates student's response to the stimulants, how he/she utilizes the stimulants in the process of learning (Claxton \& Ralston, 1978). It is a receiving and handling of information, this begins starts when the learner's focus on a new and difficult data (Dunn, 2001). Kolb, 1984 explained learning style as preferred method learners use while comprehending and processing data. Gregorc 1984 opined learning situation is dependent on perception capability of people.

Some styles have a major impact on students while on some students they don't have any impact whatsoever. Singular inclinations vary altogether, and the more grounded the inclination, the more overbearing it will have on instructional systems (Braio, Dunn, Beasley, Quinn and Buchanan, 1997). Graf \& Kinshuk (2002) in their study mentioned about difference of perception learners have about course or a learning environment. As a result, some students find course to be easy, whereas same course is found difficult by others. As per Jonassen and Grabowski (1993) the reason could be contracts learners make may incorporate their individual learning styles. Interestingly Dunn (2003) mentioned majority of the College professors don't realise that less than $30 \%$ of their students can remember approximately $70 \%$ of what they hear or see. However, if the teaching method of the professor meets the learning preference of the students there can be considerable change in the student's learning capacity. Often many students don't succeed because they are expected to sit in a class and listen to a lecture when they need active engagement to learn effectively. Felder \& Silverman (1998) pointed out in their study that if learners with a strong preference for a particular learning style, will face difficulties in learning if their learning style is not supported by the appropriate teaching strategy. Off late Business schools worldwide are experiencing a sudden decline in the number of aspirants and an increase in the number of dropouts (Giordano \& Rochford, 2005). Bajraktarevic, Hall and Fullick (2003) established the fact that by incorporating learning style learning can not only be made easier but can leads to better achievement. They confirmed this in their study on students attending an online courses in which students showed better results whose preferred learning style was considered while delivering the course than those who did not match their learning style. According to a study conducted by Graduate Management Admission Council in 2012, the median number of applications worldwide fell $22 \%$ for the 2 -years degree program. Understanding the issue at hand is required to come up with workable solutions to reduce the attrition rate.

Considerable research has been done to identify the learning style of Management students. Learning style theory has become an interesting discussion in the training and development 
literature (Campbell, 1991; Coffield , 2004). Yousef ( 2016) studied the learning style preference of statistics major at UAE university using Felder and Solomon's ILS. Findings indicated that UG statistics students from UAEU have balanced preference along the four domains of learning style. (Raju 2011) conducted the learning style preference of management students in India using Honey and Mumford learning style and indicated that students showed strong preference for "Activist" learning style . Study of the learning style preference of management and engineering students at the University of Mauritius results showed that students specialising in fields of Management had a "strong preference for Visual learning style" (Heenaye, Gobin \& Khan, 2012). Novin (2003) research on identifying the preferred learning styles as "assimilator and converger learning styles" of accounting, management and general business major students. Giordano and Rochford study on the learning styles of first-year business majors at an urban community college identified that "94 per cent of the participants were analytical learners". Pallapu (2008) examined the relationships among UG student's learning styles using the ILS parameter from the Colleges of Business, Education and Liberal Art. The researcher analyzed the relationship of gender, age, ethnicity, GPA and grade level on learning style. The result directed that "undergraduate business students preferred active (69 per cent), sensing (79 per cent), visual (77 per cent) and sequential (70 per cent) learning style" . Goorha and Mohan (2009) analyzed the learning preferences of students specializing in Management and business studies. Also, pedagogy strategies and curriculum were studied to see if they have any impact on the learning style preference. Results showed that "business students had a preference for convergence and assimilative learning". Luck and Estes's study to identify the learning styles of business studies students of a US university indicated that the students with specialization in Business had strong to moderate "preference for active, sensory, visual and sequential learning styles". Results also showed that "the largest difference is 1.58 points between accounting and marketing concentrations on the sensory/intuitive construct on an 11- point scale" (Luck \& Estes, 2011). Study conducted by Polat on the effect of learning styles of accounts students and their result showed that there is a "significant difference in the learning style on the basis of Gender, and success level in terms of academic achievements" ( Polat, Aykut, Ozpeynirci \& Duman, 2014). Bhattacharyya and Sarip work showed that there was significant difference in Male and Female learning style. Male students had a strong preference to "Visual learning style" contradictory female students liked to "think and read materials" (Bhattacharyya \& Sarip, 2013). Polat, Aykut, Ozpeynirci and Duman (2015) showed a similar result, wherein they were able to show significant difference in the learning style preference of male over female. Female students adopt "Reflector" learning style, while male students prefer "Active" learning style.

The present investigation is based on the model created by Felder and Soloman that has 4 dimensions of learning style. Felder and Soloman (2004) discuss many instructing approaches helpful to coordinate the learning preference that emerge from the use of Index of learning style as shown in the table below. 
Table 1: Attributes of the four dimensions of ILS (Felder and Soloman, 2004)

\begin{tabular}{|c|c|}
\hline \multicolumn{2}{|c|}{ Complementary learning style } \\
\hline $\begin{array}{l}\text { Sensing } \\
\text { - Draws on physical sensation } \\
\text { - Practical \& observing } \\
\text { - Prefer the concrete: facts and data } \\
\text { Prefer repetition }\end{array}$ & $\begin{array}{l}\text { Intuitive } \\
\text { - Draws on insight } \\
\text { - Imaginative and interpretative } \\
\text { - Prefer the abstract: theory and } \\
\text { modelling } \\
\text { - Prefer variation }\end{array}$ \\
\hline $\begin{array}{cl}\text { Visual } & \\
\text { - "Show me how" } \\
\text { - Prefer pictures and diagrams }\end{array}$ & $\begin{array}{l}\text { Verbal } \\
\text { - "Tell me how" } \\
\text { - Prefer writing and spoken explanation }\end{array}$ \\
\hline $\begin{array}{l}\text { Active } \\
\text { - "Let's try it out" } \\
\text { - Process information by physical activity } \\
\text { - Learn by working with others }\end{array}$ & $\begin{array}{l}\text { Reflective } \\
\text { - "Let's think it through" } \\
\text { - Process information introspectively } \\
\text { - Learn by working alone in pairs }\end{array}$ \\
\hline $\begin{array}{l}\text { Sequential } \\
\text { - Understand in continual and } \\
\text { incremental steps } \\
\text { - Linear reasoning process } \\
\text { - Convergent thinking and analysis }\end{array}$ & $\begin{array}{l}\text { Global } \\
\text { - Understand in large leaps } \\
\text { - Tacit reasoning process } \\
\text { - System thinking and synthesis }\end{array}$ \\
\hline
\end{tabular}

It was identified that few studies are conducted for students in various disciplines but no specific work in management related fields is not studied. Management is a unique field of education as experience people students carry to the classroom effects the learning.

\section{Objectives}

The literature review summary showed a lack of study on how variation in terms of degree pursuing, nationality and gender affect learning style preference. The objective of the study therefore is to identify the following:

- Explore preferred learning styles of students

- Compare learning style of Management students to other disciplines

- Analyze the relationship between learning style of a student with their Gender, Age, Educational qualification, Nationality and Past work experience

\section{Methodology}

\section{Population and sample}

The population of the current investigation comprised of full-time, students pursuing courses in the field of Science, arts and management. Total population size is 65 of which $41.5 \%$ are male and $58.5 \%$ are female. Respondents were widely segregated based on their nationality- Indians, Americans, Europeans, Moroccans, Indonesians, Omanis. 


\section{Data Collection}

Gathering of the required data was done by developing an appropriate questionnaire that comprised of two parts. The first part comprised of the Index of Learning Style survey with 44 questions that could measure the four learning style dimensions. The second component comprised of Gender, Age, Nationality, Degree pursuing, Specialisation and Work experience.

\section{Measure}

Learning style preference was recorded using Felder and Soloman's (2004) Index of Learning Style. This model comprised of 44 questions, every area containing 11 questions. They are altogether constrained decision inquiries with elective answers. ILS comprises of two restricting styles in every four spaces, active vs reflexive, sensing vs intuition, visual vs verbal and sequential vs global. Inquiries 1, 5, 9, 13, 17, 21, 25, 29, 33, 37 and 41 dissected the space of active/intelligent. Inquiries $2,6,10,14,18,22,26,30,34,38$ and 42 examined the area of sensing/instinctive. Inquiries $3,7,11,15,19,23,27,31,35,39$ and 43 examined the space of visual/verbal and Inquiries 4, 8, 12, 16, 20, 24, 28, 32, 36, 40 and 44 measured the area of sequential/global.

\section{Analysis}

Descriptive statistical analysis was done to show the demographics and other information of the respondents recorded by the questionnaire. Additionally, Two-way ANOVA was done to figure out if there were significant differences amongst the four dimension of learning styles due to respondent's Nationality, Gender, Degree pursuing and work experience.

\section{Results and Discussion}

Table 2: Student's demographics and Other details

\begin{tabular}{|c|c|c|}
\hline Characteristics & $\mathbf{N}$ & $\%$ \\
\hline Gender & & \\
\hline - Male & 27 & 41.5 \\
\hline - Female & 38 & 58.4 \\
\hline Age & & $\cdots$ \\
\hline - Less than 20 & 2 & 3 \\
\hline - 20 to less than 25 & 41 & 63 \\
\hline - 25 to less than 30 & 17 & 26.1 \\
\hline - 30 and above & 5 & 7 \\
\hline
\end{tabular}




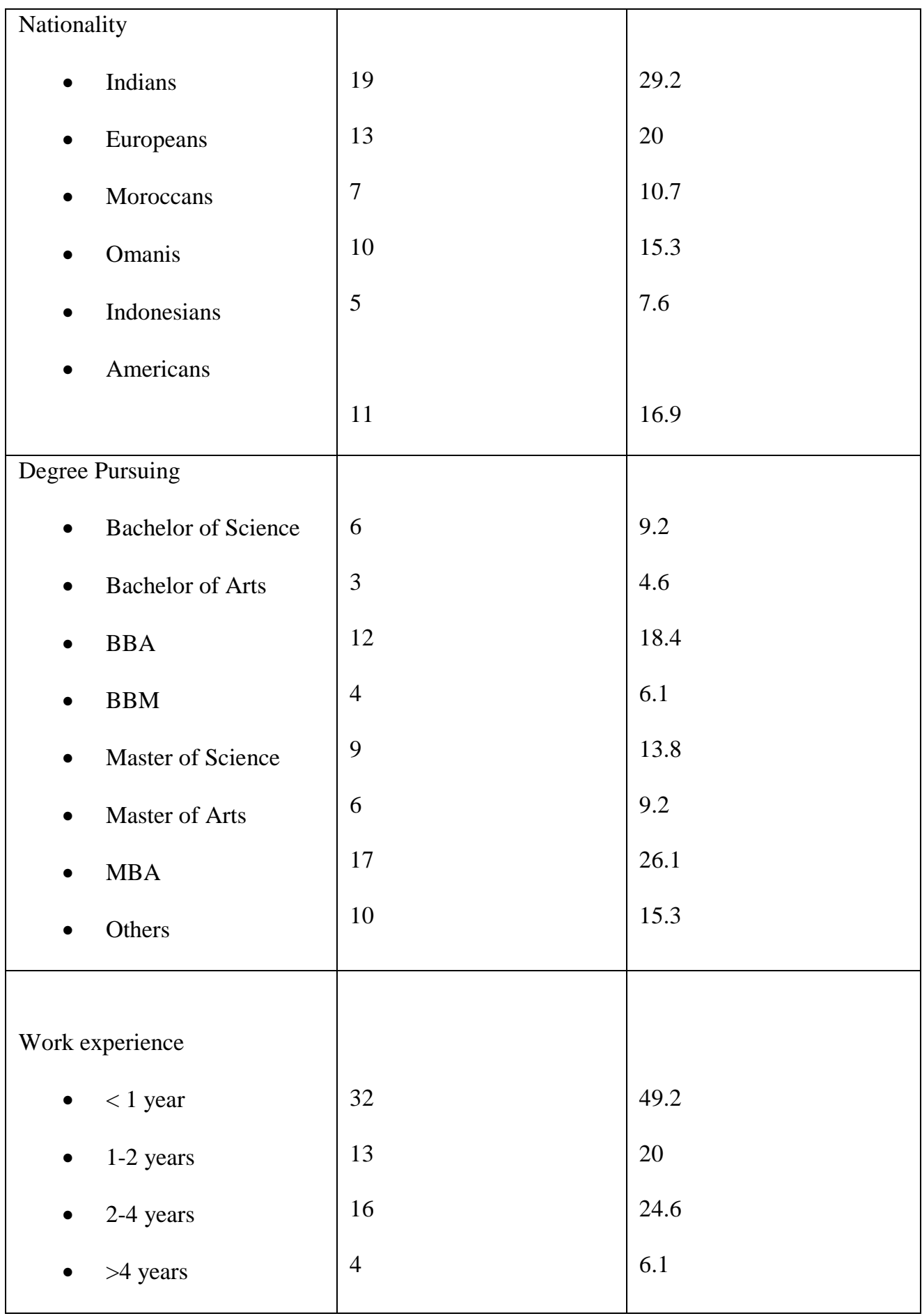

Table 2 presents data pertaining to Respondent's details recorded by the questionnaire 
Data from table 2 show that $41.5 \%$ were male and $58.4 \%$ were female. $63 \%$ of the respondents were between the age group of 20-25 years of age. Majority of the respondents were Indians (29\%) followed by Europeans (20\%), Americans (17\%), Omanis (15\%), Moroccans (11\%) and Indonesians $(8 \%)$. $26 \%$ of the respondents were pursuing MBA and $49 \%$ of the responses received had work experience which is less than 1 year.

\section{Distribution of Students based on their learning style preference}

\begin{tabular}{|c|c|c|c|c|c|c|c|}
\hline Preference & Frequency & Preference & Frequency & Preference & Frequency & Preference & Frequency \\
\hline $\begin{array}{c}\text { Strong } \\
\text { Active }\end{array}$ & - & $\begin{array}{c}\text { Strong } \\
\text { Sensing }\end{array}$ & - & $\begin{array}{c}\text { Strong } \\
\text { Visual }\end{array}$ & $2 \%$ & $\begin{array}{c}\text { Strong } \\
\text { Sequential }\end{array}$ & - \\
\hline $\begin{array}{c}\text { Moderate } \\
\text { Active }\end{array}$ & $15 \%$ & $\begin{array}{c}\text { Moderate } \\
\text { Sensing }\end{array}$ & $18 \%$ & $\begin{array}{c}\text { Moderate } \\
\text { Visual }\end{array}$ & $9 \%$ & $\begin{array}{c}\text { Moderate } \\
\text { Sequential }\end{array}$ & $18 \%$ \\
\hline Balance & $78 \%$ & Balance & $60 \%$ & Balance & $83 \%$ & Balance & $78 \%$ \\
\hline $\begin{array}{c}\text { Strong } \\
\text { Reflective }\end{array}$ & - & $\begin{array}{c}\text { Strong } \\
\text { Intuitive }\end{array}$ & $3 \%$ & $\begin{array}{c}\text { Strong } \\
\text { Verbal }\end{array}$ & $2 \%$ & Strong & $2 \%$ \\
\hline $\begin{array}{c}\text { Moderate } \\
\text { Reflective }\end{array}$ & $6 \%$ & $\begin{array}{c}\text { Moderate } \\
\text { Intuitive }\end{array}$ & $18 \%$ & $\begin{array}{c}\text { Moderate } \\
\text { Verbal }\end{array}$ & $5 \%$ & $\begin{array}{c}\text { Moderate } \\
\text { Global }\end{array}$ & $2 \%$ \\
\hline Total & $100 \%$ & Total & $100 \%$ & Total & $100 \%$ & Total & $100 \%$ \\
\hline
\end{tabular}

Table 3: Intensity of preference of Learning style

Table 3 presents data pertaining to the intensity of preference. Data in the table 3 shows that $78 \%$ of respondents had balanced preference in Active Reflective domain, with $15 \%$ had moderate preference for Active learning style. Hence, $93 \%$ of students would benefit from teaching style that included aspects of active domain. $60 \%$ of students had balanced preference in Sensing-Intuitive domain, with $3 \%$ students had strong preference for Intuitive learning and $18 \%$ students had moderate preference for the same. Hence, $81 \%$ of students would benefit from teaching style that included aspects of Intuitive domain. In the Visual-Verbal domain, 83\% of students had balanced learning style preference, of which $2 \%$ of students showed strong preference to Visual and $9 \%$ of students showed preference for Visual learning style. Hence, $94 \%$ of students would benefit from teaching style that included aspects of Visual domain. In the sequential-global domain, $78 \%$ of students had balances learning style preference. $18 \%$ of students showed moderate preference for Sequential learning. Hence, $96 \%$ of students would benefit from teaching style that included aspects of Sequential domain. Minority of students showed preference for Reflective (6\%), Sensing (18\%), Verbal (7\%) and Global (4\%) learning styles.

Also, the aggregate number of reactions is more than the quantity of respondents participated in the overview, demonstrating the point that there are respondents who have a not too high or too low preference for at least one learning style and balanced preference for the other three. 
Correlation between the learning style scores obtained from the current data

\begin{tabular}{|c|c|c|c|c|c|c|c|}
\hline Preference & Frequency & Preference & Frequency & Preference & Frequency & Preference & Frequency \\
\hline $\begin{array}{l}\text { Strong } \\
\text { Active }\end{array}$ & - & $\begin{array}{l}\text { Strong } \\
\text { Sensing }\end{array}$ & - & $\begin{array}{l}\text { Strong } \\
\text { Visual }\end{array}$ & $2 \%$ & $\begin{array}{c}\text { Strong } \\
\text { Sequential }\end{array}$ & - \\
\hline $\begin{array}{l}\text { Moderate } \\
\text { Active }\end{array}$ & $15 \%$ & $\begin{array}{l}\text { Moderate } \\
\text { Sensing }\end{array}$ & $18 \%$ & $\begin{array}{c}\text { Moderate } \\
\text { Visual }\end{array}$ & $9 \%$ & $\begin{array}{l}\text { Moderate } \\
\text { Sequential }\end{array}$ & $18 \%$ \\
\hline Balance & $78 \%$ & Balance & $60 \%$ & Balance & $83 \%$ & Balance & $78 \%$ \\
\hline $\begin{array}{l}\text { Strong } \\
\text { Reflective }\end{array}$ & - & $\begin{array}{l}\text { Strong } \\
\text { Intuitive }\end{array}$ & $3 \%$ & $\begin{array}{l}\text { Strong } \\
\text { Verbal }\end{array}$ & $2 \%$ & $\begin{array}{l}\text { Strong } \\
\text { Global }\end{array}$ & $2 \%$ \\
\hline $\begin{array}{l}\text { Moderate } \\
\text { Reflective }\end{array}$ & $6 \%$ & $\begin{array}{l}\text { Moderate } \\
\text { Intuitive }\end{array}$ & $18 \%$ & $\begin{array}{c}\text { Moderate } \\
\text { Verbal }\end{array}$ & $5 \%$ & $\begin{array}{c}\text { Moderate } \\
\text { Global }\end{array}$ & $2 \%$ \\
\hline Total & $100 \%$ & Total & $100 \%$ & Total & $100 \%$ & Total & $100 \%$ \\
\hline
\end{tabular}

Table 4: Correlation between learning style domain scores

The Karl-Pearson's correlation technique was used to show correlation of various learning style.. The scores obtained quite evidently describe the characteristics of each learning style.

\section{Impact of Gender on learning style}

\begin{tabular}{|c|c|c|c|c|c|c|c|c|c|c|c|c|}
\hline Gender & \#students & Active & Reflective & Sensing & \multicolumn{2}{|c|}{ Intuitive } & Visual & \multicolumn{2}{|l|}{ Verbal } & \multicolumn{2}{|c|}{ Sequential } & Global \\
\hline Male & 27 & 5.92 & 5.07 & 5.4 & & 5.59 & 5.6 & & 5.37 & & 5.74 & 5.25 \\
\hline Female & 38 & 6 & 5 & 5.42 & & 5.57 & 5.8 & & 5.18 & & 6.07 & 4.92 \\
\hline \multicolumn{2}{|l|}{ ANOVA } & & & & & & & & & & & \\
\hline \multicolumn{2}{|c|}{ Source of Variation } & SS & $d f$ & \multicolumn{2}{|l|}{ MS } & \multicolumn{2}{|l|}{$F$} & P-value & \multicolumn{2}{|c|}{ F crit } & & \\
\hline \multicolumn{2}{|c|}{ Between Groups } & 1.750544 & 7 & \multicolumn{2}{|c|}{0.250078} & \multicolumn{2}{|c|}{13.24476} & 0.000793 & \multicolumn{2}{|c|}{3.500464} & & \\
\hline \multicolumn{2}{|c|}{ Within Groups } & 0.15105 & 8 & \multicolumn{2}{|c|}{0.018881} & & & & \multicolumn{2}{|c|}{1} & & \\
\hline \multicolumn{2}{|c|}{ Total } & 1.901594 & 15 & & & & & & & & & \\
\hline
\end{tabular}

Table 5: Test the impact of Gender on learning style using One-Way ANOVA

H0: Gender plays null significant impact on Learning style preference (at Confidence level 95\%)

Since Fcrit value is less than Fcal value, HO is rejected. This indicates that, Gender carries a significant impact in determining the learning style preference. This result is contrary to results of Pallapu (2008), Sopian et al. (2013) and Raju (2011). However, the result is in concurrence with the research conducted by Bhattacharyya \& Sarip (2013). 


\section{Impact of Age on learning style}

$\begin{array}{lrrrrrrrrr}\text { Age } & & & & & & & \\ \text { (yrs) } & \text { \#students } & \text { Active } & \text { Reflective } & \text { Sensing } & \text { Intuitive } & \text { Visual } & \text { Verbal } & \text { Sequential } & \text { Global } \\ >20 & 2 & 6 & 5 & 4.5 & 6.5 & 6.5 & 4.5 & 6 & 5 \\ 20-25 & 41 & 5.82 & 5.17 & 5.43 & 5.6 & 5.48 & 5.51 & 5.85 & 5.14 \\ 25-30 & 17 & 6.29 & 4.7 & 5.35 & 5.64 & 5.88 & 5.11 & 6.17 & 4.82 \\ <30 & 5 & 6 & 5 & 5.8 & 5.2 & 7 & 4 & 5.8 & 5.2\end{array}$

\begin{tabular}{|c|c|c|c|c|c|c|}
\hline ANOVA & & & & & & \\
\hline Source of Variation & SS & $d f$ & MS & $F$ & P-value & F crit \\
\hline Between Groups & 8.4727 & 7 & 1.2103857 & 5.952656 & 0.000428 & 2.422629 \\
\hline Within Groups & 4.88005 & 24 & 0.2033354 & & & \\
\hline
\end{tabular}

Table 6: Test the impact of Age on learning style using One-Way ANOVA

H0: Age plays null significant impact on Learning style preference (at Confidence level 95\%)

Since Fcrit value is less than Fcal value, H0 is rejected. This indicates that, age impacts learning style preference in a significant way. This could be because of multitude of reasons, such as experience in terms of higher education, work experience, responsibilities etc.

\section{Impact of Educational qualification on learning style}

H0: Education qualification has null significant impact on learning style preference (at Confidence level 95\%)

\begin{tabular}{|c|c|c|c|c|c|c|c|c|c|}
\hline Degree & \# students & Active & Reflective & Sensing & Intuitive & Visual & Verbal & Sequential & Global \\
\hline B.Sc & 6 & 5.6 & 5.3 & 6 & 5 & 6.5 & 4.5 & 5.5 & 5.5 \\
\hline Others & 10 & 6.5 & 4.5 & 5.8 & 5.2 & 6.4 & 4.6 & 6.4 & 4.6 \\
\hline BBA & 10 & 6.2 & 4.8 & 3.9 & 7.1 & 5.3 & 5.7 & 6.1 & 4.9 \\
\hline BBM & 4 & 4.25 & 6.75 & 7 & 4 & 5.5 & 5.5 & 5.5 & 5.5 \\
\hline MBA & 17 & 6.23 & 4.76 & 5.29 & 5.7 & 5.94 & 5.05 & 6.05 & 4.94 \\
\hline BA & 3 & 5.3 & 5.6 & 4.25 & 4 & 6 & 5 & 5.3 & 5.6 \\
\hline M.Sc/M.S & 9 & 5.8 & 5.1 & 6.1 & 4.8 & 5.1 & 5.8 & 5.8 & 5.1 \\
\hline MA & 6 & 5.8 & 5.2 & 4.8 & 6.2 & 5 & 6 & 5.7 & 5.3 \\
\hline
\end{tabular}

\begin{tabular}{|c|c|c|c|c|c|c|}
\hline ANOVA & & & & & & \\
\hline Source of Variation & SS & $d f$ & MS & $F$ & P-value & F crit \\
\hline Between Groups & 3.5657234 & 7 & 0.5093891 & 0.99503 & 0.444517 & 2.178156 \\
\hline Within Groups & 28.668263 & 56 & 0.5119333 & & & \\
\hline Total & 32.233986 & 63 & & & & \\
\hline
\end{tabular}

Table 7: Test the impact of Educational qualification on learning style using One-Way NOVA 
Since Fcrit value is greater than Fcal value, H0 is accepted. This suggests that, educational qualification plays no significant role in determining the learning style preference, which goes in concurrence with research conducted by Raju (2011). A further analysis of the current data showed that management student had a strong to moderated preference for Visual learning style and balanced preference for other three domains which goes in concurrence with research conducted by Maleika at al (2012).

\section{Impact of Work experience on learning style}

H0: Work experience has null significant impact on learning style preference (at Confidence level 95\%)

\begin{tabular}{|c|c|c|c|c|c|c|c|c|c|}
\hline $\begin{array}{l}\text { Experience } \\
\text { (yrs) }\end{array}$ & $\begin{array}{l}\text { \# } \\
\text { students }\end{array}$ & Active & Reflective & Sensing & Intuitive & Visual & Verbal & Sequential & Global \\
\hline$<1$ year & 32 & 6.03 & 4.96 & 5.06 & 5.93 & 5.65 & 5.34 & 5.9 & 5.09 \\
\hline $1-2$ years & 13 & 5.53 & 5.46 & 5.76 & 5.23 & 5.38 & 5.61 & 6.3 & 4.69 \\
\hline $2-4$ years & 16 & 5.93 & 5.06 & 5.56 & 4.53 & 6 & 5 & 5.81 & 5.18 \\
\hline$>4$ years & 4 & 7 & 4 & 6.5 & 4.5 & 6.5 & 4.5 & 5.5 & 5.5 \\
\hline
\end{tabular}

\begin{tabular}{|c|c|c|c|c|c|c|}
\hline ANOVA & & & & & & \\
\hline Source of Variation & SS & $d f$ & MS & $F$ & P-value & F crit \\
\hline Between Groups & 6.4671469 & 7 & 0.9238781 & 3.253438 & 0.01421 & 2.423 \\
\hline Within Groups & 6.815275 & 24 & 0.2839698 & & & \\
\hline Total & 13.282422 & 31 & & & & \\
\hline
\end{tabular}

Table 8: Test the impact of Work experience on learning style using One-Way ANOVA

Since Fcrit value is less than Fcal value, H0 is rejected. This suggests that, work experience in years plays a significant role in determining the learning style preference. According to the current data, 93\% of Students with work experience greater than 4 years show balanced learning style, while majority of students with lower years of work experience show strong or moderate preference for at least one learning style. 


\section{Impact of Nationality on learning style}

H0: Nationality has null significant impact on learning style preference (at Confidence level $95 \%)$

\begin{tabular}{|c|c|c|c|c|c|c|c|c|c|}
\hline $\begin{array}{l}\text { Experience } \\
\text { (xrs) }\end{array}$ & $\begin{array}{l}\# \\
\text { students }\end{array}$ & Active & Reflective & Sensing & Intuitive & Visual & Verbal & Sequential & Global \\
\hline$<1$ year & 32 & 6.03 & 4.96 & 5.06 & 5.93 & 5.65 & 5.34 & 5.9 & 5.09 \\
\hline $1-2$ years & 13 & 5.53 & 5.46 & 5.76 & 5.23 & 5.38 & 5.61 & 6.3 & 4.69 \\
\hline $2-4$ years & 16 & 5.93 & 5.06 & 5.56 & 4.53 & 6 & 5 & 5.81 & 5.18 \\
\hline$>4$ years & 4 & 7 & 4 & 6.5 & 4.5 & 6.5 & 4.5 & 5.5 & 5.5 \\
\hline
\end{tabular}

\begin{tabular}{|c|c|c|c|c|c|c|}
\hline ANOVA & & & & & & \\
\hline Source of Variation & SS & $d f$ & $M S$ & $F$ & P-value & F crit \\
\hline Between Groups & 6.4671469 & 7 & 0.9238781 & 3.253438 & 0.01421 & 2.423 \\
\hline Within Groups & 6.815275 & 24 & 0.2839698 & & & \\
\hline Total & 13.282422 & 31 & & & & \\
\hline
\end{tabular}

Table 9: Test the impact of Nationality on learning style using One-Way ANOVA

Since Fcrit value is less than Fcal value, H0 is rejected. This indicates that, Nationality plays a significant role in determining the learning style preference. According to James Giordana and Regina Rochford (2005), Europeans show a significant preference for Reflective and Verbal learning style and Asians show a significant preference for analytical/sensing learning style. This was further tested using Student-t test with the current available data. A P <0.05 indicating that Europeans prefer Reflective and Verbal learning style which was in concurrence with research conducted by James Giordana and Regina Rochford (2005).

\section{Conclusion and Future Study}

Summary of findings

The present study reveals findings regarding the learning styles of students by demonstrating the following:

$>$ Respondents have a moderate preference for at least one learning style and balanced preference for the other three.

$>$ Correlation study showed negative correlation between Sensing/Reflective, Intuitive/Active, Visual/Reflective. Verbal/Sequential and Global/Reflective which supports threshold assumption.

$>$ Gender and Age assumes a noteworthy part in deciding the learning style preference.

$>$ Educational qualification plays no significant role in determining the learning style preference.

$>$ Management student tend to show strong to moderated preference for Visual learning style and balanced preference for other three domains. 
Work experience in years play a significant role in determining the learning style preference. Students with work experience greater than 4 years show balanced learning style, while students with lower years of work experience show strong or moderate preference for at least one learning style.

$>$ Nationality plays a significant role in determining the learning style preference and Europeans prefer Reflective and Verbal learning style.

Implication of the study:

$>$ The study brings interesting piece of work for higher education teachers to reflect upon their interactions with students. It adds to the complexity of challenges faced by higher education teachers. One style fits all can no more be the understanding. This also leads to bring in more innovation in teaching and learning domain.

$>$ Administrators of higher education can also relook at their evaluation pattern and identify the reasons. Literature review indicated there is increasing dropout ratio of higher education students particularly in Management courses.

$>$ Student Mentoring and Support system needs to be build to make them learn after knowing their basic learning style.

$>$ Constraints of the investigation:

$>$ Small sample estimate making it hard to sum up the outcomes.

$>$ This study reports findings that are based on self-reported questionnaire, that tends to affect the reliability of the findings.

$>$ Future work

> Further study can be conducted to discuss the following topics:

$>$ Study to deep dive on how Work experience brings in a balanced learning style preference in students and adults.

$>$ Differences of learning style among students from developed and developing nations can be studied.

$>$ Moulding of learning style to suit the subject specialization can be studied.

$>$ The topic has been studied from time to time by various author however every study reveals different aspect of learning style and its applicability to education. The topic is must to know and study for any teacher, trainer and higher education practitioners.

\section{References}

[1] Mansur K, Kogid M, Madals (2014), Learning style and its impact in Higher education and Human Capital Needs, Procedia - Social and Behavioural Sciences 123, 485 - 494.

[2] Rana Kapoor, Why we must invest more in human capital, (2017) 
[3] Seven, Bagcivan, G., Kilic, S., \& Acikel, C. (2012), Determination of the learning styles of junior nursing students and investigation of the relationship between their learning styles and academic achievement, Gülhane Tıp Derg 54: 129-135

[4] Topuz, F., Karamustafaoğlu, O. (2013). “Öğrenme Stillerinin Çeşitli Değişkenler Açısından İncelenmesi: Fen Bilgi Öğretmen Adayları”.Dicle Üniversitesi Ziya Gökalp Eğitim Fakültesi Dergisi , 30-46.

[5] Dunn, R. (1987). "Research on instructional environments: Implications for student achievement and attitudes." Professional School Psychology, 11, 43-42

[6] Dunn, R., Cavanaugh, B., Eberle, R., \& Zenhausem, R. (1982), Hemispheric preference: The newest element of learning style." The American Biology Teacher, 44, 291 294.

[7] Thies, A. P. (1979). "A brain-behavior analysis of learning style. In J. W. Keefe (ed.), Students learning styles; Diagnosis and prescribing programs”, 55-61. Reston, VA: National Association of Secondary School Principals

[8] Claxton, C. S., Ralston, Y. (1978). "Learning styles: Their impact on teaching and administration." Washington, DC: American Association for Higher Education

[9] Kolb, D. (1984) Experiential Learning. Englewood Cliffs, N.J.: Prentice-Hall.

[10] Gregorc, A. (1982) An Adult's Guide to Style. Columbia, Connecticut: Gregorc Associates.

[11] Braio, A., Dunn, R., Beasley, T. M., Quinn, P., Buchanan, K. (1997). Incremental implementation of learning style strategies among urban low achievers. Journal of Educational Research, 91, 15-25.

[12] Graf S, Kinshuk, (2009). Learning styles and cognitive traits - Their relationship and its benefits in web-based educational systems. Computers in Human Behavior, 25 (6) 12801289

[13] Jonassen, D. H., Grabowski, B. (1993). Handbook of Individual differences and instruction. Lawrence Erlbaum Associate Hillsdale, NJ.

[14] Felder \& Silverman, (1988). "Learning and Teaching Styles in Engineering Education”, Engr. Education, 78(7), 674-681

[15] Giordano \& Rochford, (2005). Understanding Business Majors' Learning Styles, Community College Enterprise, $11(.2)$

[16] Bajraktarevic, N., Hall, W., \& Fullick, P. (2003).Incorporating learning styles in hypermedia environment- Empirical evaluation. Paper presented at the Proceedings of the Workshop on Adaptive Hypermedia and Adaptive Web- Based Systems, Nottingham, UK.

[17] Campbell, B.J.(1991), Planning for a student learning style, Journal of Education for Business, 66, 356-358

[18] Coffield, F.,Moseley, D., Hall, E. Ecclestone, K.(2004), Learning styles and pedagogy - in post 16 learning: a systematic and critical review, Learning and Skills Research Centre, Institute of Education, London 
[19] Yousef D A , (2016) Learning styles preferences of statistics students: A study in the Faculty of Business and Economics at the UAE University, Quality Assurance in Education, 24 ( 2 ), 227-243

[20] Prageetha R G (2011), Determining the Learning Styles of Management Students in India Using Honey \& Mumford Learning Style Questionnaire in Bharatiya Vidyapeeth's Journal of Management Research, 3(1), April

[21] Maleika, Gobin, Baby, Khan M, Naushad. (2012). Analysis of Felder-Solomon Index of Learning Styles of Students from Management and Engineering at the University of Mauritius. Journal of Education and Vocational Research.

[22] Novin, A.M., Arjomand, L.H., Jourdan, L. (2003). An Investigation into the Preferred Learning Styles of Accounting, Management, Marketing, and General Business Majors.Teaching \& Learning, 18(1), 24-31.

[23] Pallapu, P.(2008), An exploratory study of undergraduate students' learning styles, PhD dissertation, Auburn University, Alabam

[24] Goorha, P.and Mohan, V.(2009), Understanding learning preferences in the business school curriculum, Journal of Education for Business, 85 ( 3), 145-152.

[25] Luck, G. Estes, J. (2011), Does the learning style of students depend on their area of concentration in business?, Review of Business Research, 11 (4 ) 93-100.

[26] Polat, Yusuf, Peker, A. A, Özpeynirci, R, Duman, H. (2015). The Effect of Learning Styles of Accounting Education Students on their Performance: A Field Study. Procedia - Social and Behavioral Sciences. 174. 1841-1848.

[27] Bhattacharyya, E. Sarip A B , (2013). Learning Style and Its Impact in Higher Education and Human Capital Needs. Procedia - Social and Behavioral Sciences 123, 485 - 494

[28] Felder, R.M., Soloman B.A., Index of Learning Styles (2004 - 2006), http://www.ncsu.edu/felder-public/ILSpage.html, 2004, accessed February 15, 2006.

[29] Sopian, A., Ahmad, S., Abu Bakar, K., Jamsari, E., Mat Zin, H. (2013). A study on learning styles among arabic language students at university technology Mara, Malacca Campus. IOSR Journal Of Humanities And Social Science, 15(4), 38-40

[30] P. Kanchanamala, Satish Muppidi (2016) SIPAI: An Integrated Learning Model of Self Learning, Inquiry Based, Problem Solving, Activity Based, and Instructional Learning for Engineering Education, IEEE 6th International Conference on Advanced Computing (IACC), 2016

[31] Bao H, Zhu H, Liu J, Tian F, Chen Y (2013) Analysis on Topic Map Oriented ELearner Behavior and Study Efficiency, IEEE 10th International Conference on High Performance Computing and Communications \& IEEE International Conference on Embedded and Ubiquitous Computing, 2013 